\title{
Structure and Abundance of Fusarium Communities Inhabiting the Litter of Beech Forests in Central Europe
}

\author{
Hanna Stępniewska ${ }^{1, *}$, Robert Jankowiak ${ }^{1, *}$, Piotr Bilański ${ }^{1}$ (D) and Georg Hausner ${ }^{2}$ (D) \\ 1 Department of Forest Ecosystems Protection, University of Agriculture in Krakow, Al. 29-Listopada 46, \\ 31-425 Krakow, Poland; rlbilans@cyf-kr.edu.pl \\ 2 Department of Microbiology, University of Manitoba, Buller Building 213, Winnipeg, MB R3T 2N2, Canada; \\ Georg.Hausner@umanitoba.ca \\ * Correspondence: hanna.stepniewska@urk.edu.pl (H.S.); r.jankowiak@urk.edu.pl (R.J.)
}

Citation: Stępniewska, H.;

Jankowiak, R.; Bilański, P.; Hausner,

G. Structure and Abundance of Fusarium Communities Inhabiting the Litter of Beech Forests in Central Europe. Forests 2021, 12, 811. https://doi.org/10.3390/f12060811

Academic Editor: Roberto Faedda

Received: 18 May 2021

Accepted: 17 June 2021

Published: 19 June 2021

Publisher's Note: MDPI stays neutral with regard to jurisdictional claims in published maps and institutional affiliations.

Copyright: (C) 2021 by the authors. Licensee MDPI, Basel, Switzerland. This article is an open access article distributed under the terms and conditions of the Creative Commons Attribution (CC BY) license (https:// creativecommons.org/licenses/by/ $4.0 /)$.
Abstract: Members of the genus Fusarium and related genera are important components of many ecosystems worldwide and are responsible for many plant diseases. However, the structure of beech litter-inhabiting Fusarium communities and their potential role in reducing the natural regeneration of European beech are not well understood. To address this issue, we examined Fusarium communities in the litter of uneven-aged, old-growth beech-dominated forests in the Carpathians (Poland) and in the Alps (Austria), and in a managed beech stand (Poland). The fungi inhabiting beech litter were investigated using beechnuts and pine seedlings as bait. The pathogenicity of the most common species was investigated by inoculating beech germinants. Fusarium spp. were identified based on morphology and DNA sequence comparisons of RPB2 and TEF1- $\alpha$ genes, combined with phylogenetic analyses. Twelve fungal species were identified from 402 isolates, including nine known and three currently undescribed species. The isolates resided in three species complexes within the genus Fusarium. These were the F. oxysporum (one taxon), F. sambucinum (three taxa), and F. tricinctum (six taxa) species complexes. In addition, one isolate was assigned to the genus Neocosmospora, and one isolate could be placed within the genus Fusicolla. The most frequently isolated fungi from beechnuts and beech germinants were F. avenaceum (Fr.) Sacc., F. sporotrichioides Sherb. and Fusarium sp. B. The structure and abundance of species within Fusarium communities varied by beech forest type. The species richness of Fusarium spp. was greatest in old-growth beech-dominated stands, while abundances of Fusarium spp. were higher in managed beech-dominated stands. Pathogenicity tests showed that all four Fusarium species isolated from beechnuts and beech germinants could cause germinants to rot beech, suggesting that these fungi may play a negative role in the natural beech regeneration.

Keywords: European beech; Fusarium; Fagus sylvatica; litter; natural regeneration; soil-borne fungi

\section{Introduction}

European beech (Fagus sylvatica L.) is the main broadleaved tree species in Europe's montane regions, where beech is commonly a component of mixed-species forests that includes silver fir (Abies alba Mill.), and Norway spruce (Picea abies (L.) H. Karst.) [1,2]. Beech seeds are very rich in nutrients and are consumed by many animals, including numerous bird species, mammals (primarily rodents), and several insects and molluscs. Beechnuts buried in soil for a long time may be colonized by fungi that could cause serious diseases of beechnuts and cause the rot of beech germinants [3]. Fungi are ubiquitous in soil and may affect seed survival directly by decomposition or pathogenesis [4]. Previous studies on beechnuts collected in forests showed they can be colonized by saprotrophic fungi such as Alternaria spp., Cladosporium cladosporioides (Fresen.) G.A. de Vries, Mucor hiemalis Wehmer, Penicillium spp., Rhizopus nigricans Ehrenb., Trichoderma koningii Oudem., or serious pathogens such as Rhizoctonia solani Kühn or Fusarium spp. [5-19]. These fungi can lead to seed death or alter seedling survival following germination. The results reported by 


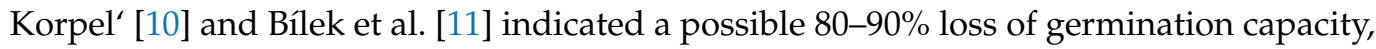
especially under wet and mild winter conditions. Large differences in beech seedling densities among regeneration patches have been reported [12], in part due to favorable climatic conditions for soil-borne fungi that become active in beech litter and cause high levels of seed mortality during the early stages of germination. In forest beech ecosystems, the population structure of soil-borne pathogens is very poorly understood. Past studies showed that among the pathogens that can cause beechnut rot, Cylindrocarpon-like fungi, such as Neonectria and Ilyonectria spp. are dominant [13]. However, the diversity of Fusarium spp. that potentially could cause beechnuts and germinants to rot under natural regeneration conditions is largely unknown.

Members of the genus Fusarium occupy various ecological niches as pathogens, as endophytes or saprotrophs in different climatic zones, particularly in tropical and subtropical regions [14]. Although Fusarium species are recognized as a threat mainly in agricultural settings, they can also induce serious losses in forestry, e.g., pitch cankers on numerous pine species caused by Fusarium circinatum Nirenberg \& O'Donnell, especially in South Africa [15]. Fusarium spp. are also well known as agents of important diseases that limit the production of seedlings in forest nurseries worldwide [16]. In forest nurseries, Fusarium species cause pre- and post-emergence damping-off, root decay, seedling wilt, stem cankers, and seed decay (e.g., [16-26]). Germinating seeds and young seedlings in nurseries can be challenged by a variety of Fusarium species such as F. oxysporum Schltdl. sensu lato, F. commune K. Skovg., O'Donnell \& Nirenberg, F. proliferatum (Matsush.) Nirenberg, F. circinatum, F. acuminatum Ellis \& Everh., F. avenaceum, F. equiseti (Corda) Sacc., F. chlamydosporum Wollenw. \& Reinking, F. tricinctum (Corda) Sacc., F. moniliforme J. Sheld., and Necosmospora solani (Mart.) L. Lombard \& Crous (formerly known as Fusarium solani (Mart.) Sacc.). Among these species, members of $F$. oxysporum sensu lato species complex are the most dominant threat $[17,21,22,26]$.

Fusarium spp. are generally soil-borne pathogens causing root and/or collar rot symptoms on young seedlings or older trees. However, information about similar disease symptoms on seedlings or trees in natural and semi-natural forests is very limited in Europe. Fusarium spp. were detected in roots of European ash (Fraxinus excelsior L.) in the former Czechoslovakia [27], and in roots of pedunculate oak (Quercus robur L.) and sessile oak (Q. petraea (Matt.) Liebl.) in Austria [28], and Poland [29]. There is no information on the occurrence of Fusarium spp. in association with the natural regeneration of forest trees, although members of this plant-pathogenic fungal group have been isolated from forest soil and litter. For example, Fusarium sp. and F. proliferatum were found in the soil of Scots pine (Pinus sylvestris L.) forests in Scotland [30] and Poland [31], while F. avenaceum and F. lateritium Nees were found on sessile oak and sycamore (Acer pseudoplatanus L.) litters in the UK [32]. The majority of ecological studies on Fusarium spp. have been performed with respect to agricultural systems, therefore members of the genus Fusarium are more frequently encountered in open land soil samples [33] compared to samples collected in regenerating and mature forests.

Outside Europe, Fusarium spp. were found in roots of naturally regenerating Douglasfir (Pseudotsuga menziesii (Mirb.) Franco) seedlings in Canada [34], and in deciduous seedlings with damping-off symptoms in Japan [35]. Pathogenic Fusarium spp. have been reported to be associated with roots and rhizosphere soil of forest trees in the west of Iran [36], while F. avenaceum and F. longipes Wollenw. \& Reinking have been recovered as damping-off pathogens in natural regenerating Eucalyptus obliqua L'Hértier and E. radiata Sieber ex DC. in Australia [37]. Recently, F. solani, F. oxysporum, F. verticillioides (Sacc.) Nirenberg, F. equiseti, F. fujikuroi Nirenberg, F. pseudocircinatum O'Donnell \& Nirenberg and F. subglutinans (Wollenw. \& Reinking) P.E. Nelson, Toussoun \& Marasas were isolated from seeds of Aspidosperma polyneuron Müll. Arg. and their ability to cause darkening of the leaf limb have been confirmed in pathogenicity trials [38]. Members of the genus Fusarium are also commonly found in soil and forest litter in other parts of the world. For example, the existence of diverse Fusarium species populations in forest soils have been reported in 
Canada [39], Australia [40], Sri Lanka [41], India [42], Malaysia [43], Argentina [44], and Indonesia [45].

The number of germinated beechnuts may be reduced by fungal pathogens inhabiting the litter layer. A recent study showed that habitants of beech litter, namely Neonectria and Ilyonectria species are pathogenic and may adversely affect the natural regeneration of $F$. sylvatica [13]. The relatively small number of Fusarium spp. reported from forestry systems might leave the impression that forests do not harbor a large diversity of these fungi, although it may also indicate that forest plants have been poorly explored in this regard. We are inclined towards the second option and hypothesize that there are many Fusarium spp. including undiscovered species associated with juvenile stages of forest trees. As part of a fungal diversity survey of beech litter in Central Europe conducted in 2011 [13], several members of the genus Fusarium occurring in larger numbers were recorded. Therefore, the objectives of this study were: (i) to characterize the diversity of Fusarium spp. and related genera in beech litter, (ii) to characterize pathogenicity of several isolates of the most frequently recovered Fusarium spp. associated with beech litter. Accordingly, this study will provide knowledge for understanding the role of Fusarium species on natural beechnuts germination and hence the survival of beech natural regeneration.

\section{Materials and Methods}

\subsection{Study Area}

The research conducted from 2010-2012 was carried out in three study sites: natural uneven-aged old-growth beech forests in the Carpathians (Babia Góra National Park, Poland, $49^{\circ} 33^{\prime} \mathrm{N}, 18^{\circ} 34^{\prime} \mathrm{E}$ ) and the Alps (Rothwald, Dürrenstein, Austria, $47^{\circ} 47^{\prime} \mathrm{N}$, $15^{\circ} 04^{\prime} \mathrm{E}$ ) and one even-aged (60-80 years old) managed beech forest in the KrakowskoCzęstochowska Highland (Zabierzowski Forest, Zabierzów, Poland, 50 $09^{\prime} \mathrm{N}, 19^{\circ} 78^{\prime} \mathrm{E}$ ). Both old-growth stands were composed of European beech, silver fir, and Norway spruce, with beech the most abundant tree species. In the Western Carpathians (Babia Gora), the elevation of the study area was between 940 and $1010 \mathrm{~m}$, and the bedrock was Carpathian flysch, a mixture of sandstone and shales. The mean annual temperature was approximately $4{ }^{\circ} \mathrm{C}$, and the annual precipitation ranged between 1300 and $1400 \mathrm{~mm}$. In the Alps (Rothwald), the elevation of the study area was between 900 and $1400 \mathrm{~m}$, and the bedrock was primarily dolomite and banked limestone. The mean annual temperature was between 4 and $5{ }^{\circ} \mathrm{C}$, and the mean annual precipitation was $2200 \mathrm{~mm}$. In the Zabierzowski Forest, the elevation was between 290 and $310 \mathrm{~m}$; the bedrock was loess covering deeper layers of limestone. The climate was mild with a mean annual temperature of approximately $8{ }^{\circ} \mathrm{C}$ and a mean annual precipitation of $700 \mathrm{~mm}$. The stand was composed of $70 \% \mathrm{Eu}-$ ropean beech; the other tree species were European ash, sycamore (Acer pseudoplatanus L.), and pedunculate oak. Detailed information regarding these locations can be found in Jankowiak et al. [13].

\subsection{Fungal Isolation}

Fusarium spp. were collected via trapping using beechnuts (experiment 1, in situ) and Scots pine (Pinus sylvestris L.) seedlings (experiment 2, in the laboratory). In situ experiments were conducted using a network of permanent sample plots established in Babia Góra National Park in 1995 and in Rothwald in 2001 for monitoring seed production and dispersal by forest trees [46]. In the Zabierzowski Forest, the experiment was conducted along a line transect as described by Jankowiak et al. [13]. In the laboratory experiment, the litter used was taken from some permanent sample plots established in Babia Góra. Pine seedlings were used to isolate a broad-spectrum of pathogenic fungi, including those related to conifers. The methodological details for both experiments have been described previously by Jankowiak et al. [13].

Experiment 1: In the stands, fifty or 25 beechnuts were placed inside perforated plastic boxes $\left(0.08 \mathrm{~m}^{3}\right.$ or $\left.0.02 \mathrm{~m}^{3}\right)$, mixed with leaf litter collected near to the site of the box in the sample plot, and finally the box was filled with litter. Then, the boxes were covered 
with a thin layer of litter and left in the forest. The boxes were placed in the autumn (October-November) in 38 sample plots in Babia Góra, 30 sample plots in Rothwald, and 10 sample plots in the Zabierzowski Forest. After wintering, the boxes were recovered in the spring (late April to late May) and taken to the laboratory. All beechnuts and beech germinants were collected and analysed. The numbers of healthy and diseased specimens were counted. The beechnuts and beech germinants affected by necrosis, and other discoloration were used for fungal isolation (Figure 1A-D).
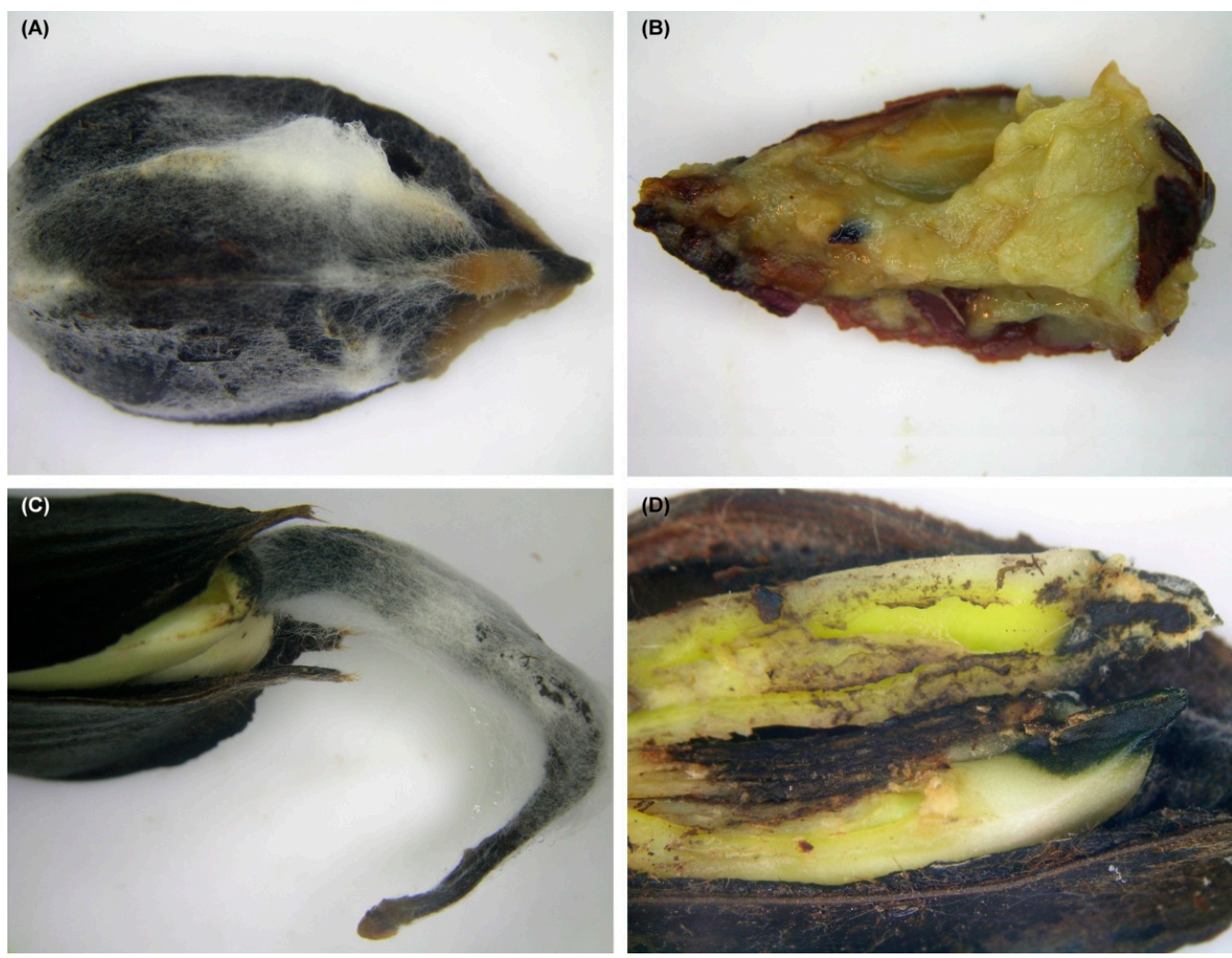

Figure 1. Fusarium-infected beechnuts and beech germinants collected from the litter in old growth beech-dominated forest (Babia Góra Forest) (A) beechnuts.; (B) late stage of cotyledon rot in beechnuts; (C) rot of beech germinant; (D) early stage of cotyledon necrosis.

Experiment 2: Litter collected from 16 sample plots in Babia Góra was mixed with a sterile peat-vermiculite substrate (a 2:1 ratio of litter to substrate) and then placed in plastic pots (volume $330 \mathrm{~mL}$ ). Thirty surface-sterilised P. sylvestris seeds had been sown in each of the five replicate pots (30 seeds per pot). The experiment was conducted in a phytotron chamber for 10 weeks. During that period, any P. sylvestris seedlings with damping-off symptoms were collected for fungal isolation.

Samples taken from both experiments, i.e., symptomatic tissues of beechnuts, beech germinants, and P. sylvestris roots were surface sterilized for $10 \mathrm{~s}$ in $96 \%$ ethyl alcohol followed by $3 \mathrm{~min}$ in $4 \% v / v$ sodium hypochlorite $(\mathrm{NaOCl})$ (Chempur, Piekary Ślaskie, Poland). Next, the tissues were rinsed three times for $3 \mathrm{~min}$ in sterile distilled water, dried on sterile blotting paper, and finally cut into smaller fragments $(5 \mathrm{~mm} \times 5 \mathrm{~mm}$ ) and placed onto $2 \%$ malt extract agar (MEA) medium (Biocorp, Warszawa, Poland) containing $2 \mu \mathrm{g} \mathrm{mL}{ }^{-1}$ tetracycline hydrochloride (Sigma-Aldrich, St. Louis, MO, USA). In summary, fungi were isolated from 842 beechnuts and 781 beech germinants (experiment 1) and the roots of 134 damped-off P. sylvestris seedlings (experiment 2).

The isolation plates were incubated in the dark at $22{ }^{\circ} \mathrm{C}$ for one week. Isolates were then transferred to fresh $2 \%$ MEA by hyphal tip transfer for purification. Isolates with fusarioid spores were retained for further study and stored at $4{ }^{\circ} \mathrm{C}$. 


\subsection{Morphological Identification}

Isolates identified as Fusarium spp. were purified by single-spore culturing. Singlespore derived isolates were cultivated on potato dextrose agar (39 $\mathrm{g} \mathrm{PDA}{ }^{-1}$, Biomaxima, Poland) and synthetic low nutrient agar (SNA) [47] and were grouped into morphotypes based on their macro- and microscopic features [48]. Depending on the number of isolates belonging to the same morphotype, 1-15 isolates per morphotype were chosen for molecular identification. The isolates are maintained in the culture collection of the Department of Forest Ecosystems Protection, the University of Agriculture in Krakow, Poland (Table 1).

Table 1. Cultures used in this study and GenBank accession numbers for sequences.

\begin{tabular}{|c|c|c|c|c|c|}
\hline \multirow{2}{*}{ Taxon } & \multirow{2}{*}{ Isolate $^{1}$} & \multirow{2}{*}{ Isolation Source } & \multirow{2}{*}{ Site } & \multicolumn{2}{|c|}{ GenBank Accession no. } \\
\hline & & & & $R P B 2$ & $T E F 1-\alpha$ \\
\hline Fusarium acuminatum & $36 \mathrm{HS}$ & Fagus sylvatica, germinants & Poland, Babia Góra & MZ078936 & MZ078975 \\
\hline \multirow[t]{15}{*}{ Fusarium avenaceum } & P49HS & Fagus sylvatica, germinants & Austria, Rothwald & MZ078937 & MZ078976 \\
\hline & P40HS & Fagus sylvatica, germinants & Poland, Babia Góra & MZ078938 & MZ078977 \\
\hline & $43 \mathrm{HS}$ & Fagus sylvatica, germinants & Poland, Zabierzowski Forest & MZ078939 & MZ078978 \\
\hline & P56HS & Fagus sylvatica, germinants & Poland, Zabierzowski Forest & MZ078940 & MZ078979 \\
\hline & 3HS & Pinus sylvestris, seedlings & Poland, Babia Góra & MZ078941 & MZ078980 \\
\hline & P53HS & Fagus sylvatica, germinants & Austria, Rothwald & MZ078942 & MZ078981 \\
\hline & $35 \mathrm{HS}$ & Fagus sylvatica, germinants & Poland, Babia Góra & MZ078943 & MZ078982 \\
\hline & 17HS & Fagus sylvatica, germinants & Poland, Babia Góra & MZ078944 & MZ078983 \\
\hline & $1 \mathrm{HS}$ & Pinus sylvestris, seedlings & Poland, Babia Góra & MZ078945 & MZ078984 \\
\hline & $34 \mathrm{HS}$ & Fagus sylvatica, beechnuts & Poland, Babia Góra & MZ078946 & MZ078985 \\
\hline & $37 \mathrm{HS}$ & Fagus sylvatica, germinants & Poland, Babia Góra & MZ078947 & MZ078986 \\
\hline & $20 \mathrm{HS}$ & Fagus sylvatica, beechnuts & Poland, Babia Góra & MZ078948 & MZ078987 \\
\hline & $53 \mathrm{HS}$ & Fagus sylvatica, germinants & Poland, Zabierzowski Forest & MZ078949 & MZ078988 \\
\hline & $46 \mathrm{HS}$ & Fagus sylvatica, germinants & Poland, Zabierzowski Forest & MZ078950 & MZ078989 \\
\hline & P41HS & Fagus sylvatica, germinants & Poland, Babia Góra & MZ078951 & MZ078990 \\
\hline Fusarium graminearum & $5 \mathrm{HS}$ & Pinus sylvestris, seedlings & Poland, Babia Góra & MZ078952 & MZ078991 \\
\hline Fusarium oxysporum & $23 \mathrm{HS}$ & Fagus sylvatica, beechnuts & Poland, Babia Góra & MZ078953 & MZ078992 \\
\hline \multirow[t]{2}{*}{ Fusarium sambucinum } & 14HS & Fagus sylvatica, beechnuts & Poland, Babia Góra & MZ078954 & MZ078993 \\
\hline & 47HS & Fagus sylvatica, germinants & Poland, Zabierzowski Forest & MZ078955 & MZ078994 \\
\hline \multirow[t]{3}{*}{ Fusarium sporotrichioides } & 4HS & Pinus sylvestris, seedlings & Poland, Babia Góra & MZ078956 & MZ078995 \\
\hline & $42 \mathrm{HS}$ & Fagus sylvatica, germinants & Poland, Zabierzowski Forest & MZ078957 & MZ078996 \\
\hline & $48 \mathrm{HS}$ & Fagus sylvatica, germinants & Poland, Zabierzowski Forest & MZ078958 & MZ078997 \\
\hline Fusarium tricinctum & P55HS & Fagus sylvatica, beechnuts & Poland, Babia Góra & MZ078959 & MZ078998 \\
\hline \multirow[t]{2}{*}{ Fusarium A } & 8HS & Fagus sylvatica, beechnuts & Poland, Babia Góra & MZ078924 & MZ078963 \\
\hline & 7HS & Fagus sylvatica, germinants & Poland, Babia Góra & MZ078925 & MZ078964 \\
\hline \multirow[t]{9}{*}{ Fusarium B } & $54 \mathrm{HS}$ & Fagus sylvatica, germinants & Poland, Zabierzowski Forest & MZ078926 & MZ078965 \\
\hline & 10HS & Fagus sylvatica, germinants & Poland, Babia Góra & MZ078927 & MZ078966 \\
\hline & $31 \mathrm{HS}$ & Fagus sylvatica, germinants & Poland, Babia Góra & MZ078928 & MZ078967 \\
\hline & 11HS & Fagus sylvatica, germinants & Poland, Babia Góra & MZ078929 & MZ078968 \\
\hline & $18 \mathrm{HS}$ & Fagus sylvatica, germinants & Poland, Babia Góra & MZ078930 & MZ078969 \\
\hline & $29 \mathrm{HS}$ & Fagus sylvatica, germinants & Poland, Babia Góra & MZ078931 & MZ078970 \\
\hline & $30 \mathrm{HS}$ & Fagus sylvatica, beechnuts & Poland, Babia Góra & MZ078932 & MZ078971 \\
\hline & 61HS & Fagus sylvatica, germinants & Austria, Rothwald & MZ078933 & MZ078972 \\
\hline & $62 \mathrm{HS}$ & Fagus sylvatica, germinants & Austria, Rothwald & MZ078934 & MZ078973 \\
\hline Fusarium C & 27HS & Fagus sylvatica, beechnuts & Poland, Babia Góra & MZ078935 & MZ078974 \\
\hline \multirow[t]{3}{*}{ Neocosmospora solani } & $25 \mathrm{HS}$ & Fagus sylvatica, beechnuts & Poland, Babia Góra & MZ078960 & MZ078999 \\
\hline & $26 \mathrm{HS}$ & Fagus sylvatica, beechnuts & Poland, Babia Góra & MZ078961 & MZ079000 \\
\hline & 50HS & Fagus sylvatica, germinants & Poland, Babia Góra & MZ078962 & MZ079001 \\
\hline Fusicolla sp. & $16 \mathrm{HS}$ & Fagus sylvatica, germinants & Poland, Babia Góra & - & MZ079002 \\
\hline
\end{tabular}

${ }^{1}$ In bold isolates used in pathogenicity tests.

\subsection{DNA Extraction, Amplification and Phylogenetic Analysis}

DNA was extracted using the Genomic Mini AX Plant Kit (A\&A Biotechnology, Gdynia, Poland) according to the manufacturer's protocol. DNA was amplified in a $25 \mu \mathrm{L}$ reaction mixture containing $0.25 \mu \mathrm{L}$ of Phusion High-Fidelity DNA polymerase (Finnzymes, Espoo, Finland), $5 \mu \mathrm{L}$ of Phusion HF buffer ( $5 \mathrm{X}, 0.5 \mu \mathrm{L}$ of dNTPs $(10 \mathrm{mM})$, $0.75 \mu \mathrm{L}$ of DMSO $(100 \%)$ and $0.5 \mu \mathrm{L}$ of each primer $(25 \mu \mathrm{M})$. Amplification of the gene regions was performed under the following conditions: a denaturation step at $98^{\circ} \mathrm{C}$ for $30 \mathrm{~s}$ followed by 35 cycles of $5 \mathrm{~s}$ at $98^{\circ} \mathrm{C}, 10 \mathrm{~s}$ at $52-64{ }^{\circ} \mathrm{C}$ (depending on the optimal melting temperature of the primers and fungal species) and $30 \mathrm{~s}$ at $72{ }^{\circ} \mathrm{C}$ and a final chain elongation step at $72{ }^{\circ} \mathrm{C}$ for $8 \mathrm{~min}$. The amplification reactions were performed using a LabCycler thermocycler (SensoQuest Biomedical Electronics GmbH, Göttingen, Germany). For sequencing and phylogenetic analyses, two loci were amplified: RNA polymerase second largest subunit (RPB2), and the translation elongation factor 1- alpha (TEF1- $\alpha$ ). The primers used for PCR and sequencing of the various gene regions were as follows: RPB2-5F2 
and fRPB2-7cR or fRPB2-7cF and fRPB2-11aR [49,50] for RPB2; EF1/EF2 [51] for TEF1- $\alpha$. The isolates were identified to the species level by conducting Basic Local Alignment Search Tool (BLAST) searches with Fusarium-ID [52] and GenBank sequence data. BLAST searches [53] using the BLASTn algorithm were performed to retrieve similar sequences from GenBank (http:/ / www.ncbi.nlm.nih.gov, accessed on 1 April 2021). The reference sequences came from several taxonomic reports [54-58], including ex-type cultures of Fusarium spp. Datasets were curated with the Molecular Evolutionary Genetic Analysis (MEGA) v6.06 program [59]. The first analysis based on TEF1- $\alpha$ sequences was conducted to assess the preliminary identification of the isolates and their phylogenetic affinity among the different species complexes (SC) of Fusarium and related genera. In this study, TEF1- $\alpha$ combined with RPB2 were used for phylogenetic analysis of four Fusarium SC and for the genus Necosmospora.

For phylogenetic analyses, sequence alignments were performed using the online version of MAFFT v7 [60]. The RPB2 and TEF1- $\alpha$ datasets were aligned using the E-INSi strategy with a 200PAM/ $\mathrm{K}=2$ scoring matrix, a gap opening penalty of 1.53 , and an offset value of 0.00. The alignments were checked manually with BioEdit v.2.7.5 [61]. The resulting alignments and trees were deposited into TreeBASE (http:/ / purl.org/phylo/ treebase/phylows/study/TB2:S28194, accessed on 4 May 2021).

Phylogenetic trees were inferred for each of the datasets using three different methods: Maximum likelihood (ML), Maximum Parsimony (MP), and Bayesian inference (BI). For ML and $\mathrm{BI}$ analyses, the best-fit substitution models for each aligned dataset were established using the corrected Akaike Information Criterion (AICc) in jModelTest 2.1.10 [62,63]. ML analyses were carried out with PhyML 3.0 [64], utilizing the Montpelier online server (http://www.atgc-montpellier.fr/phyml/, accessed on 15 April 2021). The ML analysis included bootstrap analysis (1000 bootstrap pseudoreplicates) to assess node support values and the overall reliability of the tree topology.

MP analyses were performed using PAUP* $4.0 \mathrm{~b} 10$ (Swofford D.L., Sunderland, MA, USA) [65]. Gaps were treated as the fifth state. Bootstrap analysis (1000 bootstrap replicates) was conducted to determine the levels of confidence for the nodes within the inferred tree topologies. Tree bisection and reconnection (TBR) was selected as the branch swapping option. The tree length (TL), Consistency Index (CI), Retention Index (RI), Homoplasy Index (HI), and Rescaled Consistency Index (RC) were recorded for each analysed dataset after the trees were generated.

BI analyses using Markov Chain Monte Carlo (MCMC) methods were carried out with MrBayes v3.1.2 [66]. The four MCMC chains were run for 10 million generations applying the best-fit model for each data set. Trees were sampled every 100 generations, resulting in 100,000 trees. The Tracer v1.4.1 program [67] was utilized to determine the burn-in value for each dataset. The remaining trees were utilized to generate a $50 \%$ majority-rule consensus tree, which allowed for calculating posterior probability values for the nodes.

All sequences generated in this study were deposited in NCBI GenBank (Table 1) and are presented in the phylogenetic trees. All analyses were first run independently for each gene partition. The resulting trees were visually compared for topological incongruences. Gene partitions showing no topological incongruence were combined for the final analyses presented here. The different partitions and conditions used for each analysis are shown in Table 2.

\subsection{Pathogenicity Tests}

Fusarium avenaceum, F. sambucinum Fuckel, F. sporotrichioides, and Fusarium sp. B associated with symptomatic beechnuts and / or beech germinants were used for inoculation (two isolates per species) (Table 1). Five healthy germinants (about 10-15 mm long) were placed on a 9-cm plastic Petri plate covered with sterile moistened blotting paper. The germinants were inoculated with 5 -mm plugs taken from the margin of a 10-14-dayold fungal culture growing on a PDA medium. Five germinants were inoculated with sterile PDA as negative controls. The plates were wrapped with Parafilm ${ }^{\circledR}$ (Amcor, Zürich, 
Switzerland) and stored at $15^{\circ} \mathrm{C}$ in the dark. After 14 days, the number of germinants with visible necroses were recorded. Fusarium was re-isolated from symptomatic germinants on a PDA medium. The experiment was repeated twice.

Table 2. Characteristics of the gene partitions used in this study.

\begin{tabular}{|c|c|c|c|c|c|c|c|c|c|c|}
\hline \multirow{2}{*}{ Dataset $^{1}$} & \multirow{2}{*}{ Locus $^{2}$} & \multirow{2}{*}{$\begin{array}{l}\text { Substitution } \\
\text { Model }^{3}\end{array}$} & \multicolumn{4}{|c|}{ Number of Sites } & \multicolumn{4}{|c|}{ Parsimony Statistics } \\
\hline & & & Total & Cons. ${ }^{4}$ & Var. ${ }^{5}$ & Phy.i. ${ }^{6}$ & $\mathrm{CI}^{7}$ & $\mathbf{R I}^{8}$ & $\mathrm{RC}^{9}$ & $\mathrm{HI}^{10}$ \\
\hline Neocosmospora spp. & $\begin{array}{c}\text { Combined } \\
R P B 2+T E F 1-\alpha\end{array}$ & $\mathrm{GTR}+\mathrm{I}+\mathrm{G}$ & 1396 & 909 & 181 & 306 & 0.504 & 0.638 & 0.322 & 0.496 \\
\hline Fusarium tricinctum SC & $\begin{array}{c}\text { Combined } \\
R P B 2+T E F 1-\alpha\end{array}$ & $\mathrm{GTR}+\mathrm{I}+\mathrm{G}$ & 1407 & 1010 & 33 & 364 & 0.785 & 0.917 & 0.72 & 0.215 \\
\hline Fusarium sambucinum SC & $\begin{array}{c}\text { Combined } \\
R P B 2+T E F 1-\alpha\end{array}$ & $\mathrm{GTR}+\mathrm{G}$ & 1647 & 1109 & 15 & 523 & 0.804 & 0.929 & 0.747 & 0.196 \\
\hline Fusarium oxysporum SC & $\begin{array}{c}\text { Combined } \\
R P B 2+T E F 1-\alpha\end{array}$ & $\mathrm{HKY}+\mathrm{G}$ & 1497 & 1305 & 90 & 102 & 0.835 & 0.861 & 0.719 & 0.165 \\
\hline
\end{tabular}

${ }^{1}$ SC species complex; ${ }^{2}$ RPB2 RNA polymerase second largest subunit; TEF translation elongation factor $1-\alpha ;{ }^{3}$ GTR generalized time-reversible model; G gamma distribution; I proportion of invariable sites; HKY Hasegawa-Kishino-Yano; ${ }^{4}$ Conserved; ${ }^{5}$ Variable; ${ }^{6}$ Phylogenetically informative; ${ }^{7} \mathrm{CI}$ consistency index; ${ }^{8} \mathrm{RI}$ retention index; ${ }^{9} \mathrm{RC}$ rescaled CI; ${ }^{10} \mathrm{HI}$ homoplasy Index.

\section{Results}

\subsection{Fungal Isolation}

In total, 402 fungal isolates resembling Fusarium spp. have been collected. Of these, 375 isolates were isolated from beechnuts and beech germinants (Experiment 1), whereas 27 isolates were obtained from pine roots (Experiment 2).

\subsection{Fungal Identification and Phylogenetic Analysis}

Comparison of the TEF1- $\alpha$ sequences with sequences in GenBank and FUSARIUM-ID database confirmed their phylogenetic affinities among the different species complexes (SC) of Fusarium and related genera. The isolates were distributed into three Fusarium SC, namely the F. oxysporum SC (FOSC, one isolate), F. sambucinum SC (FSAMSC, six isolates), and the F. tricinctum SC (FTSC, 29 isolates). Three isolates (25HS, 26HS, and 50HS) belonged to the genus Neocosmospora, and one isolate (16HS) represented the genus Fusicolla.

Within the F. oxysporum SC, one isolate was identified as F. oxysporum sensu stricto (Figure 2). The F. sambucinum SC was represented by three species. In this species complex, $R P B 2$ and TEF1- $\alpha$ sequences of one isolate were identical to that of $F$. graminearum Schwabe, three isolates represented F. sporotrichioides, while two isolates were F. sambucinum (Figure 3). The RPB2 and TEF1- $\alpha$ sequences for 29 isolates in the F. tricinctum SC showed that these isolates represented three known and three unknown taxa. The known species were represented by F. acuminatum (one isolate), F. avenaceum (15 isolates), and F. tricinctum (one isolate) (Figure 4). Two isolates named as Fusarium sp. A, and nine isolates named as Fusarium sp. B formed two distinct lineages most closely related to F. avenaceum (Figure 4). Within the FTSC, Fusarium sp. A formed a new lineage, while isolates of Fusarium sp. B belonged to the FTSC 5 (Figure 4). One of the isolates referred to herein as Fusarium sp. C, formed a separate clade close to F. acuminatum and F. tricinctum (Figure 4). The genus Neocosmospora was represented by one species: Neocosmospora solani (Figure 5). 


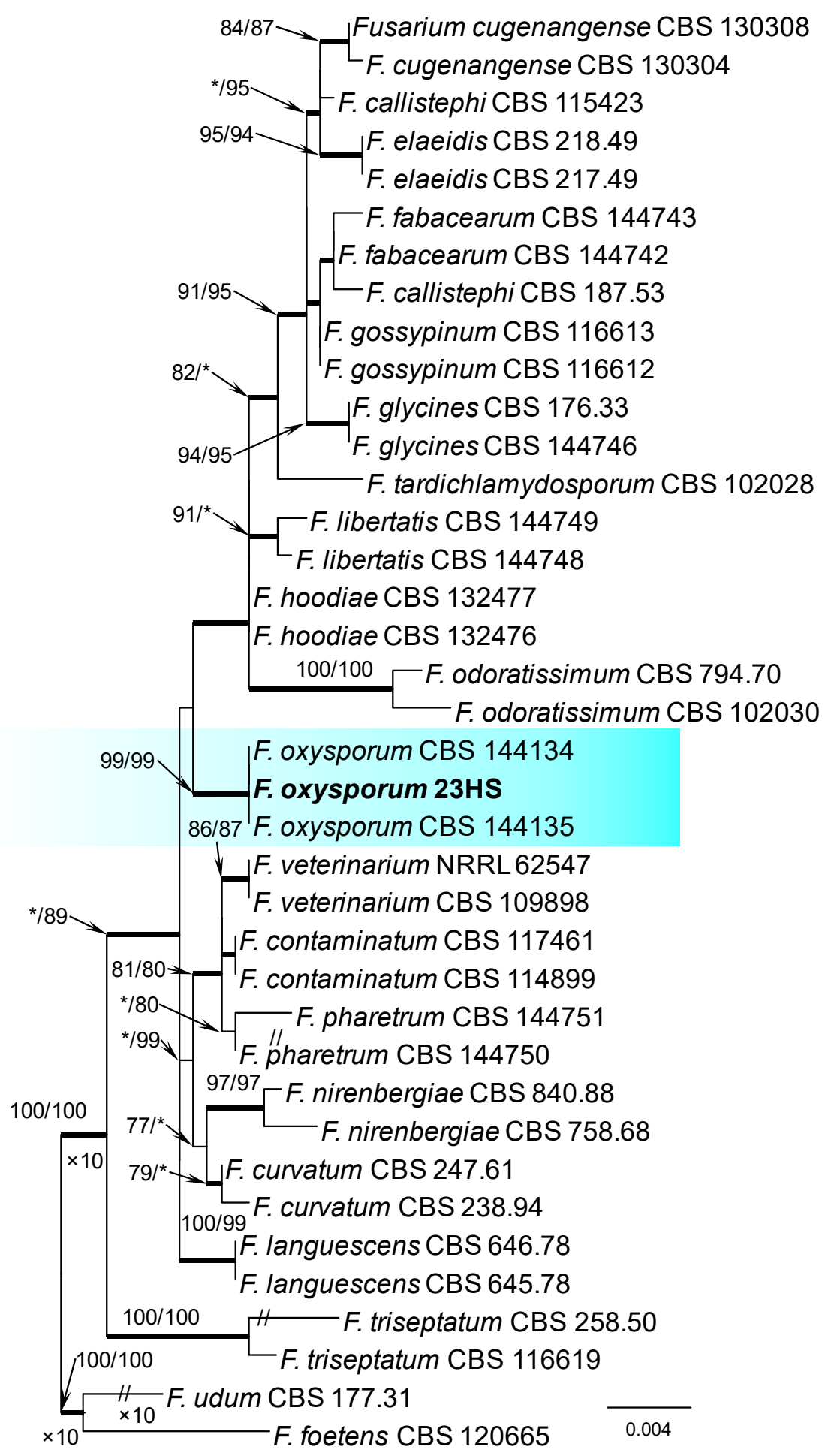

Figure 2. Phylogram obtained from Maximum Likelihood (ML) analysis of the combined dataset of RPB2+TEF1- $\alpha$ for selected species of the Fusarium oxysporum SC. Sequence obtained during this study is presented in bold font. The Bootstrap values $\geq 75 \%$ for ML and Maximum Parsimony (MP) analyses are presented at nodes as follows: ML/MP. Bold branches indicate posterior probabilities values $\geq 0.95$ obtained from Bayesian Inference (BI) analyses. ${ }^{*}$ Bootstrap values $<75 \%$. The tree is drawn to scale (see bar) with branch length measured in the number of substitutions per site. Fusarium foetens and Fusarium udum represent the outgroup in analyses of the combined dataset of $R P B 2+T E F 1-\alpha$. 


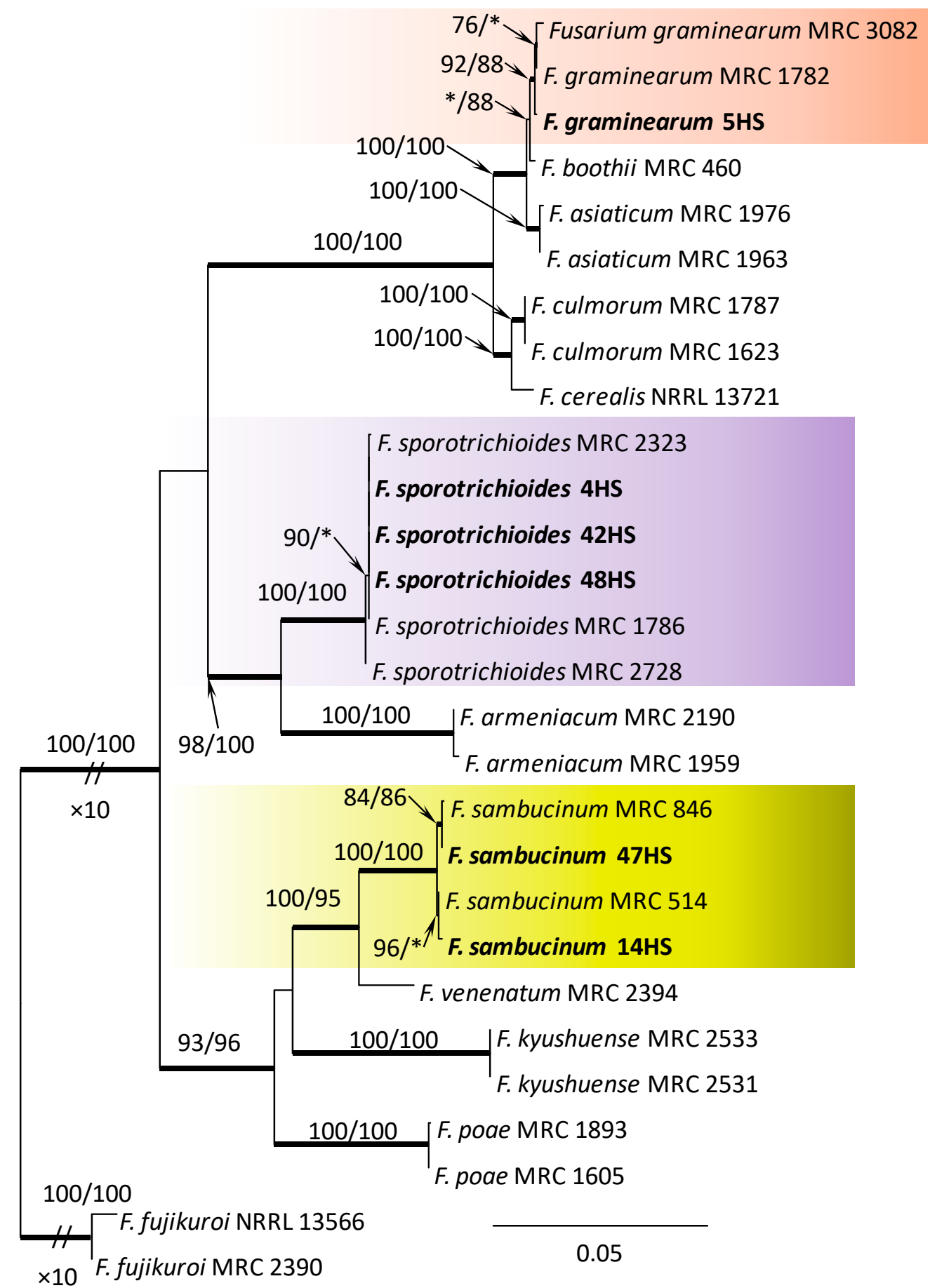

Figure 3. Phylogram obtained from Maximum Likelihood (ML) analysis of the combined dataset of $R P B 2+T E F 1-\alpha$ for selected species of the Fusarium sambucinum SC. Sequences obtained during this study are presented in bold font. The Bootstrap values $\geq 75 \%$ for ML and Maximum Parsimony (MP) analyses are presented at nodes as follows: ML/MP. Bold branches indicate posterior probabilities values $\geq 0.95$ obtained from Bayesian Inference (BI) analyses. ${ }^{*}$ Bootstrap values $<75 \%$. The tree is drawn to scale (see bar) with branch length measured in the number of substitutions per site. Fusarium fujikuroi represents the outgroup in the analysis of the combined dataset of RPB2+TEF1- $\alpha$. 


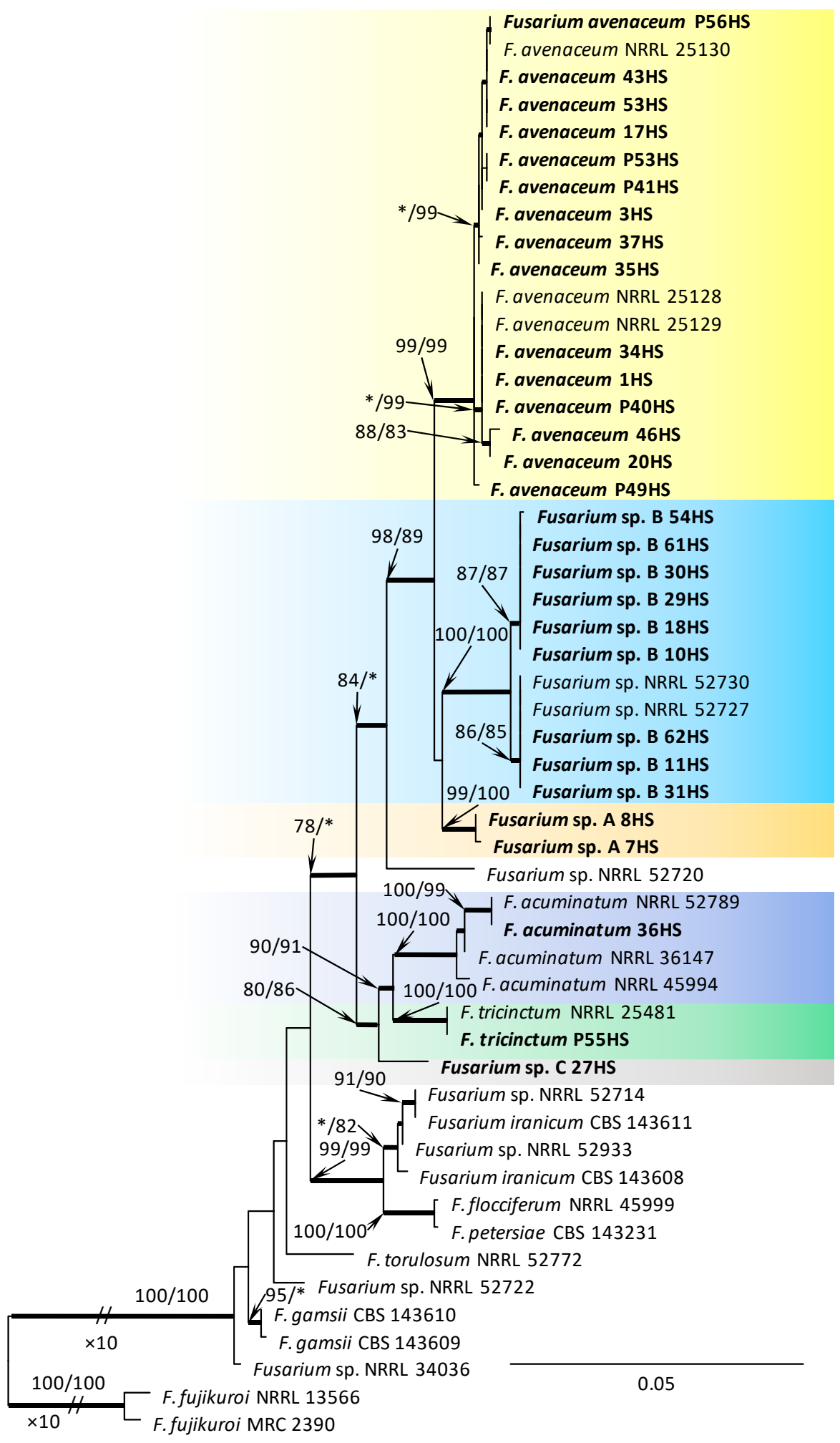

Figure 4. Phylogram obtained from Maximum Likelihood (ML) analysis of the combined dataset of RPB2+TEF1- $\alpha$ for selected species of the Fusarium tricinctum SC. Sequences obtained during this study are presented in bold font. The Bootstrap values $\geq 75 \%$ for ML and Maximum Parsimony (MP) analyses are presented at nodes as follows: ML/MP. Bold branches indicate posterior probabilities values $\geq 0.95$ obtained from Bayesian Inference (BI) analyses. ${ }^{*}$ Bootstrap values $<75 \%$. The tree is drawn to scale (see bar) with branch length measured in the number of substitutions per site. Fuarium fujikuroi represents the outgroup in the analysis of the combined dataset of RPB2+TEF1- $\alpha$. 


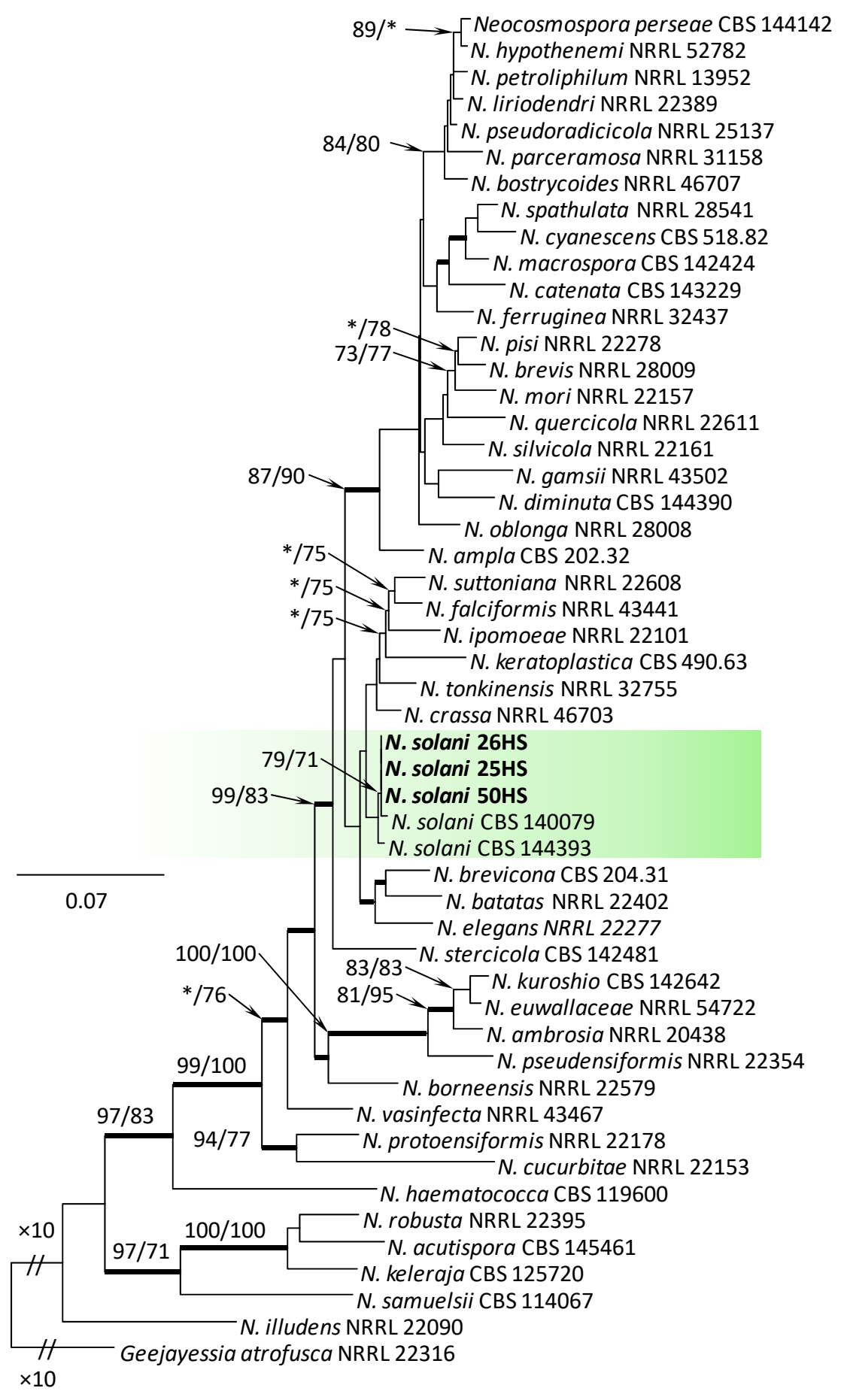

Figure 5. Phylogram obtained from Maximum Likelihood (ML) analysis of the combined dataset of RPB2+TEF1- $\alpha$ for selected species of Neocosmospora spp. Sequences obtained during this study are presented in bold font. The Bootstrap values $\geq 75 \%$ for ML and Maximum Parsimony (MP) analyses are presented at nodes as follows: ML/MP. Bold branches indicate posterior probabilities values $\geq 0.95$ obtained from Bayesian Inference (BI) analyses. ${ }^{*}$ Bootstrap values $<75 \%$. The tree is drawn to scale (see bar) with branch length measured in the number of substitutions per site. Geejayessia atrofusca represents the outgroup in the analysis of the combined dataset of RPB2+TEF1- $\alpha$.

The TEF1- $\alpha$ sequence of isolate $16 \mathrm{HS}$ was $99 \%$ identical to Fusicolla aquaeductuum (Radlk. \& Rabenh.) Gräfenhan, Seifert \& Schroers (isolate CBS 835.85) [68]. 


\subsection{Frequency of Isolation of Fusarium spp. and Related Genera from Beech Litter}

Experiment 1: The members of the F. tricinctum SC were the most commonly isolated, and $F$. avenaceum was the dominant member among the Fusarium spp. isolated, found in $9.3 \%$ to $65.2 \%$ of beechnuts and beech germinants. This fungus had the highest isolation frequency $(65.2 \%)$ from the Zabierzowski Forest. The lowest isolation frequency of $F$. avenaceum $(9.3 \%$ ) was obtained in Babia Góra (Table 3). Fusarium sp. B, the next most frequently isolated Fusarium species from beechnuts and beech germinants were isolated from 2.1 to $5.8 \%$ of specimens (Table 3). Additionally, F. sporotrichioides was isolated at varying frequencies having the highest isolation frequency $(10.1 \%)$ in the Zabierzowski Forest, and the lowest isolation frequency (from $0 \%$ to $0.8 \%$ ) in Babia Góra and Rothwald (Table 3). Other Fusarium species, Fusicolla sp., and Neocosmospora solani were sporadically isolated (from $0.1 \%$ to $2.9 \%$ ) (Table 3). The genera Fusarium, Fusicolla, and Neocosmospora were most commonly isolated in the managed forest, Zabierzowski Forest $(79.7 \%)$. In contrast, the frequencies of these fungi in the natural forests (Babia Góra and Rothwald) were considerably lower (19.3\% and $16.8 \%$, respectively) (Table 3$)$.

Table 3. Isolation frequency (\%) of Fusarium and related genera from the beech litter collected at the three study sites.

\begin{tabular}{|c|c|c|c|c|}
\hline \multirow[b]{3}{*}{ Taxon } & \multicolumn{4}{|c|}{ Locations } \\
\hline & \multicolumn{2}{|c|}{ Babia Góra } & \multirow{2}{*}{$\begin{array}{c}\text { Rothwald } \\
\text { Experiment } 1 \text { In Situ } \\
\text { (Beechnuts or } \\
\text { Beech Germinants) }\end{array}$} & \multirow{2}{*}{$\begin{array}{c}\text { Zabierzowski Fores } \\
\text { Experiment } 1 \text { In Sit } \\
\text { (Beechnuts or } \\
\text { Beech Germinants) }\end{array}$} \\
\hline & $\begin{array}{l}\text { Experiment } 1 \text { In Situ } \\
\text { (Beechnuts or } \\
\text { Beech Germinants) }\end{array}$ & $\begin{array}{c}\text { Experiment } 2 \\
\text { in Laboratory } \\
\text { (Pine Seedlings) }\end{array}$ & & \\
\hline Fusarium acuminatum & 1.6 & & & \\
\hline Fusarium avenaceum & 9.3 & 16.7 & 13.2 & 65.2 \\
\hline Fusarium graminearum & & 1.4 & & \\
\hline Fusarium oxysporum & 1.6 & & & \\
\hline Fusarium sambucinum & 0.5 & & 0.2 & 2.9 \\
\hline Fusarium sporotrichioides & & 1.4 & 0.8 & 10.1 \\
\hline Fusarium tricinctum & 0.3 & & & \\
\hline Fusarium sp. A & 0.7 & & & \\
\hline Fusarium sp. B & 4.3 & & 2.1 & 5.8 \\
\hline Fusarium sp. C & 0.1 & & & \\
\hline Fusicolla sp. & 0.1 & & & \\
\hline Neocosmospora solani & 0.2 & & 0.8 & \\
\hline $\begin{array}{l}\text { Fusarioid species (Fusarium, } \\
\text { Fusicolla and Neocosmospora), total }\end{array}$ & 18.9 & 19.6 & 16.8 & 79.7 \\
\hline $\begin{array}{l}\text { Cylindrocarpon-like species } \\
\text { (Ilyonectria and Neonectria), total }^{1}\end{array}$ & 31.9 & 48.3 & 43.2 & 39.1 \\
\hline
\end{tabular}

\footnotetext{
${ }^{1}$ Data from Jankowiak et al. [13].
}

Experiment 2: Only three Fusarium species were found in the litter from Babia Góra. Like experiment 1, the most abundant species was F. avenaceum, found in $16.7 \%$ of dying $P$. sylvestris seedlings (Table 3). Fusarium graminearum and F. sporotrichioides were sporadically isolated $(1.4 \%)$. Isolates of $F$. graminearum have been detected only in this experiment (Table 3).

\subsection{Pathogenicity}

Inoculation of beech germinants with isolates of F. avenaceum, F. sambucinum, F. sporotrichioides, and Fusarium sp. B resulted in extensive necrosis on all germinants; no necrosis occurred in control germinants (Figure 6A-F). All the fungal species were successfully re-isolated from the inoculated germinants. 

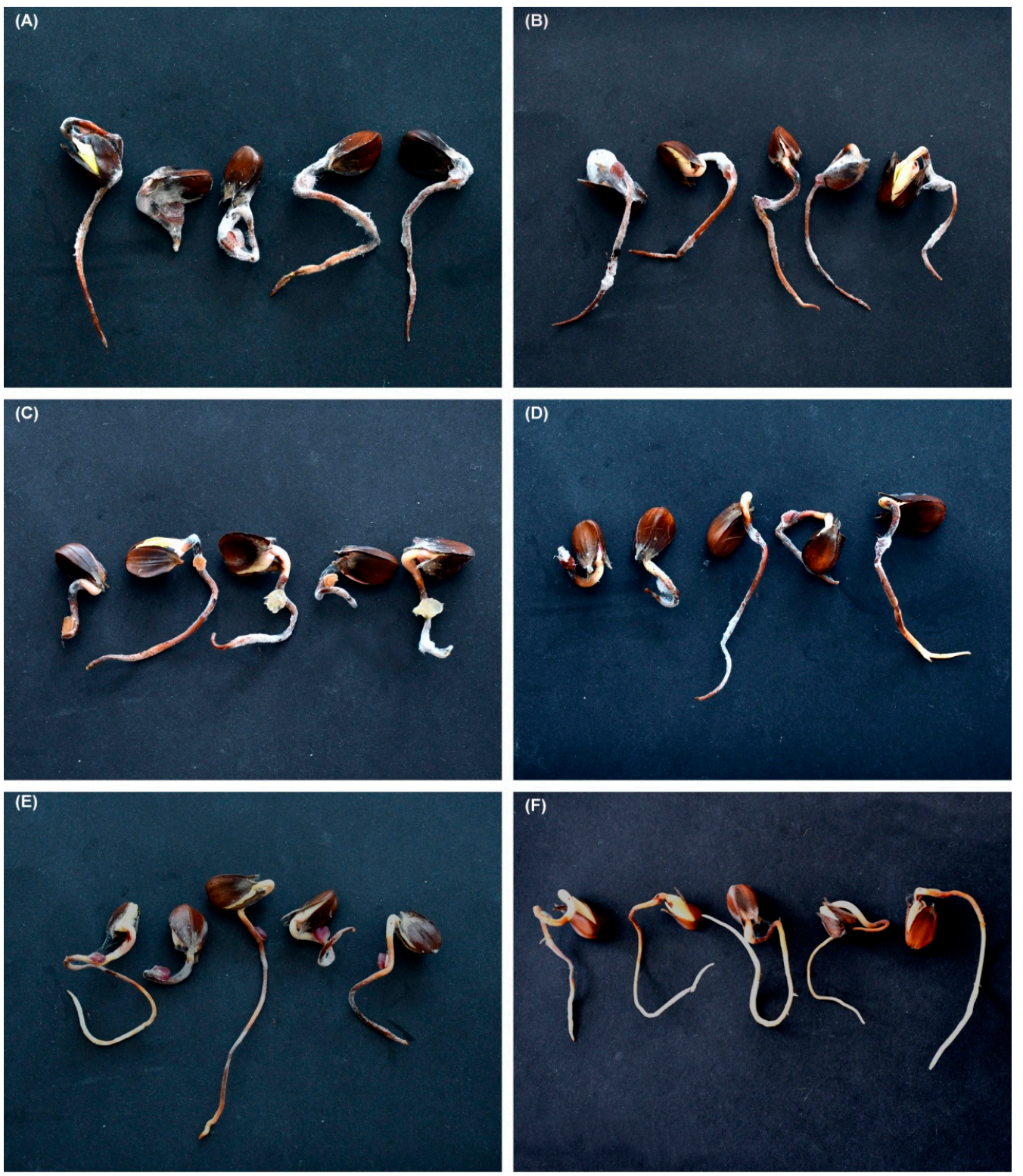

Figure 6. Necrosis on beech germinants inoculated with: (A) Fusarium avenaceum (53HS); (B) F. avenaceum (17HS); (C) F. sambucinum (14HS); (D) F. sporotrichioides (48HS); (E) Fusarium sp. B (10HS); (F) control.

\section{Discussion}

This study resulted in the recovery of 402 isolates of Fusarium and related genera from natural and semi-natural beech-dominated woodlands in Central Europe, where these fungi are largely unstudied. The fungi included species of Fusarium, Neocosmospora solani, and Fusicolla sp. The phylogenetic analysis showed that these isolates could be assigned to 12 distinct taxa, of which four represented undescribed species; and $F$. avenaceum, $F$. sporotrichioides, and Fusarium sp. B were the most commonly detected. Isolates of $F$. avenaceum, F. sambucinum, F. sporotrichioides, and Fusarium sp. B were also determined to be virulent on beech germinants.

This study not only illustrated the widespread nature of Fusarium distribution in the litter of beech forests in Central Europe, but also established, for the first time that Fusarium spp. can be major germinants pathogens in the natural regeneration of beech in this area. The pathogenicity tests in this study showed that Fusarium spp. caused severe symptoms on the beech germinants. These findings highlight the importance of beech 
litter as a disease reservoir for germinating beechnuts. This agrees with findings from a study in Poland [13], wherein the same samples from beech forests, isolation of pathogenic Ilyonectria spp. and Neonectria spp. ranged from 32 to $48 \%$. Our work confirmed that beechnuts lying on the litter surface or buried within the litter are exposed to a wide range of potentially damaging agents. Among them, fungal pathogens belonging to Fusarium spp., Ilyonectria spp., and Neonectria spp. seems to be very important for beechnuts viability and therefore have a negative role in the natural regeneration of beech. We suggest that this is an important mechanism contributing to the lack of seedlings after mast years when the beechnuts that survived until spring on the forest floor were numerous but almost no seedlings are present.

In the present study, among the 10 recorded Fusarium species, there were five species namely F. avenaceum, F. oxysporum, F. sambucinum, F. sporotrichioides [69], and N. solani [8] that had been previously detected on beechnuts after harvest and after drying in Poland. These pathogens have also been reported as causal agents of damping-off in tree seedlings in forest nurseries $[16,18,25]$. It cannot be excluded that Fusarium spp. inhabiting beech litter may be disseminated via seed and spread within forest nurseries. A similar phenomenon in seed-borne Fusarium pathogens of Pinus ponderosa Dougl. ex C. Lawson were observed by Salerno et al. [70], who showed that many different Fusarium species are carried on seeds of P. ponderosa in Argentina that may serve as inoculum sources for damping-off and root rot diseases in forest nurseries.

Fusarium avenaceum was the most frequently encountered species in our study, found in association with beechnuts and beech germinants at all study sites. It indicates that F. avenaceum is a major agent responsible for the decline of beechnuts in Central Europe. This fungus can cause damage to many agricultural crops worldwide, including forest nurseries [19,71,72]. Fusarium avenaceum has also been recorded in the natural regenerating of Eucalyptus seedlings with causing damping-off symptoms in Australia [37]. This species has also been isolated from the roots of forest trees in Iran [36], forest litter in Sri Lanka [41], oak and sycamore litter in the UK [32], and from symptomatic shoots of Q. robur in Poland [73,74].

Fusarium sporotrichioides and Fusarium sp. B were also isolated relatively frequently from infected beechnuts and beech germinants in this survey. The pathogenicity tests in this study showed that isolates of both Fusarium species were able to induce necrosis on beech germinants, which may suggest that these species have the potential to reduce the natural regeneration of beech. Fusarium sporotrichioides is widespread across tropical and temperate regions [75] and is commonly associated with seedling diseases in forest nurseries [16], wilt symptoms and needle dieback on mature trees [76] or cankers [77]. This fungus was also found in beechnuts [8] and insect-damaged acorns of $Q$. robur [78]. In turn, an undescribed species named as Fusarium sp. B is the member of Fusarium tricinctum species complex (FTSC 5), and the phylogenetic analysis showed that this taxon is closely related to F. avenaceum. The RPB2 and TEF1- $\alpha$ sequences of Fusarium sp. B obtained in this study were identical to isolates of Fusarium sp. reported from Turkey (NRRL 52730, NRRL 52227) [55,58]. Interestingly, isolates matching Fusarium sp. B have been recovered from the symptomatic stems of young seedlings in naturally regenerated oaks in Poland [79], indicated that this Fusarium species is commonly distributed in hardwood forests in Poland. The Fusarium tricinctum species complex (FTSC) was also represented by two other unknown taxa: Fusarium sp. A and Fusarium sp. C. All unknown Fusarium species detected in this study (Fusarium sp. A-C) probably represent new taxa and will be described elsewhere.

Fusarium oxysporum, the most common Fusarium damping-off pathogen in bareroot forest nurseries $[3,16]$, was detected only sporadically in diseased tissues of beechnuts and beech germinants, although it is known from other types of forests. It has been recovered in forest litter and soil in many regions of the world (e.g., [39,40,43,44,80-82]) as well as in the roots of forest trees in Iran [36]. This study provides the first information about the presence of F. oxysporum in the litter in beech forests. 
There were large quantitative and qualitative differences in the Fusarium spp. composition between the two examined types of forests, i.e., natural old-growth beech forests with a small admixture of $A$. alba and P. abies (Babia Góra, Rothwald), and managed beech forest with a small admixture of different hardwood species (Zabierzowski Forest). The highest species richness value was found in a natural old-growth beech forest in Babia Góra (10 species) while the lowest species richness value occurred in a managed beech forest in Zabierzowski Forest (4 species). It is possible that old beech forest enriched with conifers could promote some Fusarium species. On the contrary, the least complex Fusarium community was found in managed and relatively tree species poor Zabierzowski Forest. Recent studies have shown that, the most important factor that shape soil microbiome community assemblages are the tree hosts promoted by complex interactions, including alteration of the microclimate (temperature and moisture), production of litter, production of root exudates, or direct interactions with root-symbiotic and root-associated microorganisms [83,84].

The abundance of various Fusarium spp. also differed among the forest types. The abundance of Fusarium spp., especially F. avenaceum, F. sambucinum, and F. sporotrichioides in managed beech-dominated stand was considerably higher than in an old growth beechdominated forest. The high Fusarium spp. abundance in the managed beech-dominated stand may be due to their host preference for hardwood trees. A comparative analysis of the occurrence of Fusarium spp. and Cylindrocarpon-like fungi (Ilyonectria spp. and Neonectria spp.) that have been collected from the same sites by Jankowiak et al. [13] showed that Cylindrocarpon-like fungi had no host preferences although the occurrence of Ilyonectria species appeared to be more closely related to the presence of conifers in temperate forests.

\section{Conclusions}

We showed that Fusarium spp. are diverse and important components of the litter mycobiota in beech forests and that they may play a negative role in the natural regeneration of beech. The results suggest that the structure and abundance of Fusarium communities inhabiting the litter may vary depending on the beech forest composition. However, further studies on the presence of Fusarium spp. on different forest trees are needed. Although, an increasing number of studies on soil fungal communities in forest ecosystems have recently been conducted in many countries, the results of our study highlight the fact that only a small proportion of litter fungi are currently known. This survey of Fusarium spp. in beech litter revealed three new Fusarium species belonging to the Fusarium tricinctum species complex (FTSC) for which the taxonomic status needs to be clarified in further studies. This supports the view that the diversity of Fusarium species and related genera in forest litter in Central Europe is high.

Author Contributions: H.S. conceived the idea and performed the fungal isolation and pathogenicity experiment, R.J. and P.B. analyzed the molecular data, H.S., R.J. and P.B. wrote the manuscript, and G.H. reviewed and approved the final manuscript. All authors have read and agreed to the published version of the manuscript.

Funding: This work was supported by the Ministry of Science and Higher Education of the Republic of Poland.

Institutional Review Board Statement: Not applicable.

Informed Consent Statement: Not applicable.

Data Availability Statement: The data presented in this study are available on request from the first author.

Acknowledgments: We would like to thank Beata Strzałka and Grzegorz Bednarz for their help in laboratory works, and Jerzy Szwagrzyk from University of Agriculture in Krakow in beechnuts collection.

Conflicts of Interest: The authors declare no conflict of interest. 


\section{References}

1. Bolte, A.; Czajkowski, T.; Kompa, T. The north-eastern distribution range of European beech-A review. Forestry 2007, 80, 413-429. [CrossRef]

2. Paluch, J.; Kołodziej, Z.; Pach, M.; Jastrzębski, R. Spatial variability of close-to-primeval Fagus-Abies-Picea forests in the Western Carpathians (Central Europe): A step towards a generalized pattern. Eur. J. For. Res. 2015, 134, 235-246. [CrossRef]

3. Barna, M. Natural regeneration of Fagus sylvatica L.: A Review. Austrian J. For. Sci. 2011, 128, 71-91.

4. Crist, T.O.; Friese, C.F. The Impact of Fungi on Soil Seeds: Implications for Plants and Granivores in a Semiarid Shrub-Steppe. Ecology 1993, 74, 2231-2239. [CrossRef]

5. Walz, A.K.E.; Hindorf, H. Occurrence of Pythium ultimum and Fusarium arthsporioides on beech-nuts (Fagus sylvatica). J. Plant. Dis. Prot. 1989, 96, 633-635.

6. Mittal, R.K.; Anderson, R.L.; Mathur, S.B. Micro-Organisms Associated with Tree Seeds, World Checklist 1990; Information Report PI-X-96E/F; National Forestry Institute: Petawawa, ON, Canada, 1990; 70p.

7. Prochazkova, Z. Quality, and fungus contamination, of European beech (Fagus sylvatica) beechnuts collected from the forest floor and from nets spread on the floor. Zpravy Lesn. Vyzk. 2009, 54, 205-212.

8. Król, E.; Machowicz-Stefaniak, Z.; Zimowska, B.; Abramczyk, B. Grzyby zasiedlające nasiona wybranych gatunków drzew leśnych. Sylwan 2015, 159, 135-141. [CrossRef]

9. Perera, R.H.; Hyde, K.D.; Maharachchikumbura, S.S.N.; Jones, E.B.G.; McKenzie, E.H.C.; Stadler, M.; Lee, H.B.; Samarakoon, M.C.; Ekanayaka, A.H.; Camporesi, E.; et al. Fungi on wild seeds and fruits. Mycosphere 2020, 11, 2108-2480. [CrossRef]

10. Korpel', Š. Zaciatocné fázy prirodzenej obnovy bukových porastov. In Pestovanie a Produkcia Buka; Zachar, D., Štefancík, L., Eds.; Príroda: Bratislava, Slovakia, 1978; pp. 109-141.

11. Bílek, L.; Remeš, J.; Zahradník, D. Natural regeneration of senescent even-aged beech (Fagus sylvatica L.) stands under the conditions of Central Bohemia. J. For. Sci. 2009, 55, 145-155. [CrossRef]

12. Szewczyk, J.; Szwagrzyk, J. Spatial and temporal variability of natural regeneration in a temperate old-growth forest. Ann. For. Sci. 2010, 67, 202. [CrossRef]

13. Jankowiak, R.; Stępniewska, H.; Szwagrzyk, J.; Bilański, P.; Gratzer, G. Characterization of Cylindrocarpon-like species associated with litter in the old-growth beech forests of Central Europe. For. Path. 2016, 46, 582-594. [CrossRef]

14. Babadoost, M. Fusarium: Historical and Continued Importance. In Fusarium-Plant Diseases, Pathogen Diversity, Genetic Diversity, Resistance and Molecular Markers; Askun, T., Ed.; IntechOpen: London, UK, 2018; pp. 13-24. [CrossRef]

15. Wingfield, M.J.; Hammerbacher, R.J.; Ganley, R.J.; Steenkamp, E.; Gordon, T.R.; Wingfield, B.D.; Coutinho, T.A. Pitch canker caused by Fusarium circinatum-a growing threat to pine plantations and forests worldwide. Australas Plant Path. 2008, 37, 319-334. [CrossRef]

16. James, R.L.; Dumroese, R.K. Investigations of Fusarium diseases within Inland Pacific Northwest Forest Nurseries. In Guyon J.C. Comp. 2006. Proceedings of the 53 Western International Forest Disease Work Conference, Jackson, WY, USA, 26-29 August 2005; Jackson, W.Y., Ogden, U.T., Eds.; U.S. Department of Agriculture, Forest Service, Intermountain Region: Jackson, WY, USA, 2006 ; pp. 3-11.

17. Dumroese, R.K.; James, R.L. Root diseases in bareroot and container nurseries of the Pacific Northwest: Epidemiology, management, and effects on outplanting performance. New For. 2005, 30, 185-202. [CrossRef]

18. Montecchio, L. Damping-off of Beech Seedlings Caused by Fusarium avenaceum in Italy. Plant Dis. 2005, 89, 1014. [CrossRef] [PubMed]

19. Lilja, A.; Poteri, M.; Petäistö, R.-L.; Rikala, R.; Kurkela, T.; Kasanen, R. Fungal diseases in forest nurseries in Finland. Silva. Fenn. 2010, 44, 525-545. [CrossRef]

20. Peterson, M. Fusarium species-a British Columbia Perspective in Forest Seedling Production. In National Proceedings: Forest and Conservation Nursery Associations-2007; Dumroese, R.K., Riley, L.E., Technical Coordinators; Proceedings RMRS-P-57; USDA Forest Service, Rocky Mountain Research Station: Fort Collins, CO, USA, 2008; pp. 109-125. Available online: http: //www.fs.fed.us/rm/pubs/rmrs_p057.html (accessed on 23 September 2020).

21. Martin-Pinto, P.; Pajares, J.A.; Pando, V.; Diez, J.J. Fungi isolated from diseased nursery seedlings in Spain. New For. 2006, 31, 41-56. [CrossRef]

22. Menkis, A.; Vasiljauskas, R.; Taylor, A.F.S.; Stenström, E.; Stenlid, J.; Finlay, R. Fungi in decayed roots of conifer seedlings in forest nurseries, afforested clear-cuts and abandoned farmland. Plant Pathol. 2006, 55, 117-129. [CrossRef]

23. Zakeri, A.; Hamzeharghani, H.; Banihashemi, Z.; Saadati, S.H. Pathogenic fungi associated with pre- and post-emergence seedling blight of pine and cypress in Fars Province, Iran. For. Path. 2011, 41, 438-443. [CrossRef]

24. Lazreg, F.; Belabid, L.; Sanchez, J.; Gallego, E.; Bayaa, B. Pathogenicity of Fusarium spp. associated with diseases of Aleppo-pine seedlings in Algerian forest nurseries. J. For. Sci. 2014, 60, 115-120. [CrossRef]

25. Okorski, A.; Pszczółkowska, A.; Kokorska, A.; Fordoński, G. First Report of Fagus sylvatica infection by Fusarium avenaceum in Forest Container Nurseries in Northeastern Poland. Plant Dis. 2015, 99, 420. [CrossRef]

26. Fajardo, M.A.; Leon, J.D.; Correa, G.A.; Morales, J.G. The Causal Agent of Damping-off Pinus patula (Schiede) and Pinus tecunumanii (Schwerdtf.). Floresta Ambient. 2019, 26, e20190050. [CrossRef]

27. Kubíková, J. The surface mycoflora of ash roots. Trans. Brit. Mycol. Soc. 1963, 46, 107-114. [CrossRef]

28. Halmschlager, E.; Kowalski, T. The mycobiota in nonmycorrhizal roots of healthy and declining oaks. Can. J. Bot. 2004, 82, 1446-1458. [CrossRef] 
29. Bartnik, C. Symptomy chorobowe i uszkodzenia w systemach korzeniowych zamierajacych dębów oraz grzyby im towarzyszące. In "Fitopatologia wczoraj, dziś i jutro"; Materiaty z Sympozjum 75 lat Katedry Fitopatologii SGGW w Warszawie, 23-24 września; Majewski, T., Ed.; Exit: Warsaw, Poland, 1997; pp. 3-10.

30. Chavarriaga, D.; Bodles, W.J.A.; Leifert, C.; Belbahri, L.; Woodward, S. Phytophthora cinnamomi and other fine root pathogens in north temperate pine forests. FEMS Microbiol. Lett. 2007, 276, 67-74. [CrossRef] [PubMed]

31. Kwaśna, H.; Behnke-Borowczyk, J.; Gornowicz, R.; Łakomy, P. Effects of preparation of clear-cut forest sites on the soil mycobiota with consequences for Scots pine growth and health. For. Path. 2019, 49, e12494. [CrossRef]

32. Newsham, K.K. Response of saprotrophic fungal communities to declining $\mathrm{SO}_{2}$ pollution in the natural environment. Pedobiologia 2003, 47, 77-84. [CrossRef]

33. Shi, L.; Dossa, G.G.O.; Paudel, E.; Zang, H.; Xu, J.; Harrison, R.D. Changes in fungal communities across a forest disturbance gradient. Appl. Environ. Microbiol. 2019, 85, e00080-19. [CrossRef]

34. Axelrood, P.E.; Chapman, W.K.; Seifert, K.A.; Trotter, D.B.; Shrimpton, G. Cylindrocarpon and Fusarium root colonization of Douglas-fir seedlings from British Columbia reforestation sites. Can. J. For. Res. 1998, 28, 1198-1206. [CrossRef]

35. Yamazaki, M.; Iwamoto, S.; Seiwa, K. Distance- and density-dependent seedling mortality caused by several diseases in eight tree species co-occurring in a temperate forest. Plant Ecol. 2009, 201, 181-196. [CrossRef]

36. Chehri, K.; Salleh, B.; Soleimani, M.J.; Reddy, K.R.N.; Zakaria, L. Occurrence of Fusarium spp. Associated with root tissues and rhizosphere soils of forest trees and assessment of their pathogenicity on Prunus amygdalus seedlings. Aust. J. Bot. 2010, 58, 679-686. [CrossRef]

37. Mwanza, E.J.M.; Kellas, J.D. Identification of the fungi associated with damping-off in the regeneration of Eucalyptus obliqua and E. radiata in a central Victorian forest. Eur. J. For. Pathol. 1987, 17, 237-245. [CrossRef]

38. Mazarotto, E.J.; Poitevin, C.G.; do Carmo, A.L.M.; dos Santos, A.F.; Tralamazza, S.M.; Pimentel, I.C. Pathogenic Fusarium species complexes associated to seeds of indigenous Brazilian forest tree Aspidosperma polyneuron. Eur. J. Plant Pathol. 2020, 158, 849-857. [CrossRef]

39. Weidensaul, T.C.; Wood, F.A. Sources of Species of Fusarium in Northern Hardwood Forests. Phytopathology 1973, 63, 367-371. [CrossRef]

40. Summerell, B.A.; Rugg, C.A.; Burgess, L.W. Mycogeography of Fusarium: Survey of Fusarium species associated with forest and woodland communities in north Queensland, Australia. Mycol. Res. 1993, 97, 1015-1019. [CrossRef]

41. Kannangara, B.T.S.D.P.; Deshappriya, N. Microfungi associated with leaf litter decomposition of Michelia nilagirica and Semecarpus coriacea at Hakgala Montane Forest. J. Natn. Sci. Found. Sri Lanka 2005, 33, 81-91. [CrossRef]

42. Sharma, G.; Pandey, R.R.; Singh, M.S. Microfungi associated with surface soil and decaying leaf litter of Quercus serrata in a subtropical natural oak forest and managed plantation in Northeastern India. Afr. J. Microbiol. Res. 2011, 5, 777-787. [CrossRef]

43. Manshor, N.; Rosli, H.; Ismail, N.A.; Salleh, B.; Zakaria, L. Diversity of Fusarium Species from Highland Areas in Malaysia. Trop. Life Sci. Res. 2012, 23, 1-15.

44. Allegrucci, N.; Bucsinszky, A.M.; Arturi, M.; Cabello, M.N. Comunities of anamorphic fungi on green leaves and leaf litter of native forests of Scutia buxifolia and Celtis tala: Composition, diversity, seasonability and substrate specificity. Rev. Iberoam. Micol. 2015, 32, 71-78. [CrossRef] [PubMed]

45. Rambey, R.; Sianturi, S.D. Decomposition rate of Rhizopora stylosa litter in Tanjung Rejo Village, Deli Serdang Regeney, North Sumatera Province. International Conference of Agriculture, Environment and Food Security. In IOP Conference Series: Earth and Environmental Science; IOP: London, UK, 2008; Volume 122, p. 012058. [CrossRef]

46. Szwagrzyk, J.; Gratzer, G.; Steppniewska, H.; Szewczyk, J.; Veselinovic, B. High reproductive effort and low recruitment rates of European beech; is there a limit for the superior competitor? Pol. J. Ecol. 2015, 63, 243-257. [CrossRef]

47. Nirenberg, H. Untersuchungen uber die morphologische und biologische Differenzierung in der Fusarium-Section Liseola. Mitt. Biol. Bundesanst. Land Forstwirtsch. 1976, 169, 1-117.

48. Leslie, J.F.; Summerell, B.A. The Fusarium Laboratory Manual; Blackwell Publishing: Ames, IA, USA, 2006; pp. 1-388.

49. Liu, Y.J.; Whelen, S.; Hall, B.D. Phylogenetic relationships among ascomycetes: Evidence from an RNA polymerase II subunit. Mol. Biol. Evol. 1999, 16, 1799-1808. [CrossRef] [PubMed]

50. Sung, G.H.; Sung, J.M.; Hywel-Jones, N.L.; Spatafora, J.W. A multi-gene phylogeny of Clavicipitaceae (Ascomycota, fungi): Identification of localized incongruence using a combinational bootstrap approach. Mol. Phylogenet. Evol. 2007, 44, $1204-1223$. [CrossRef]

51. O'Donnell, K.; Kistler, H.C.; Cigelnik, E.; Ploetz, R.C. Multiple evolutionary origins of the fungus causing Panama disease of banana: Concordant evidence from nuclear and mitochondrial gene genealogies. Proc. Natl. Acad. Sci. USA 1998, 95, 2044-2049. [CrossRef] [PubMed]

52. Geiser, D.M.; del Mar Jiménez-Gasco, M.; Kang, S.; Makalowska, I.; Veeraraghavan, N.; Ward, T.J.; Zhang, N.; Kuldau, G.A.; O'donnell, K. FUSARIUM-ID v. 1.0: A DNA Sequence Database for Identifying Fusarium. Eur. J. Plant Pathol. 2004, 110, 473-479. [CrossRef]

53. Altschul, S.F.; Gish, W.; Miller, W.; Myers, E.W.; Lipman, D.J. Basic local alignment search tool. J. Mol. Biol. 1990, 215 , 403-410. [CrossRef]

54. Crous, P.W.; Wingfield, M.J.; Burgess, T.I.; Carnegie, A.J.; Hardy, G.S.; Smith, D.; Summerell, B.A.; Cano-Lira, J.F.; Guarro, J.; Houbraken, J.; et al. Fungal Planet description sheets: 625-715. Persoonia 2017, 39, 270-467. [CrossRef] [PubMed] 
55. O’Donnell, K.; McCormick, S.P.; Busman, M.; Proctor, R.H.; Ward, T.J.; Doehring, G.; Geiser, D.M.; Alberts, J.; Rheeder, J.P. Marasas et al. 1984 "Toxigenic Fusarium Species: Identity and Mycotoxicology" revisited. Mycologia 2018, 110, 1058-1080. [CrossRef]

56. Sandoval-Denis, M.; Lombard, L.; Crous, P. Back to the roots: A reappraisal of Neocosmospora. Pers. Mol. Phylogeny Evol. Fungi 2019, 43, 90-185. [CrossRef]

57. Lombard, L.; Sandoval-Denis, M.; Lamprecht, S.C.; Crous, P. Epitypification of Fusarium oxysporum-clearing the taxonomic chaos. Pers. Mol. Phylogeny Evol. Fungi 2019, 43, 1-47. [CrossRef]

58. Torbati, M.; Arzanlou, M.; Sandoval-Denis, M.; Crous, P.W. Multigene phylogeny reveals new fungicolous species in the Fusarium tricinctum species complex and novel hosts in the genus Fusarium from Iran. Mycol. Prog. 2019, 18, 119-133. [CrossRef]

59. Tamura, K.; Stecher, G.; Peterson, D.; Filipski, A.; Kumar, S. MEGA6: Molecular Evolutionary Genetics Analysis version 6.0. Mol. Biol. Evol. 2013, 30, 2725-2729. [CrossRef] [PubMed]

60. Katoh, K.; Standley, D.M. MAFFT multiple sequence alignment software version 7, improvements in performance and usability. Mol. Biol. Evol. 2013, 30, 772-780. [CrossRef]

61. Hall, T.A. BioEdit: A user-friendly biological sequence alignment editor and analysis program for Windows 95/98/NT. Nucl Acid. S. 1999, 41, 95-98. [CrossRef]

62. Guindon, S.; Gascuel, O. A simple, fast and accurate method to estimate large phylogenies by maximum-likelihood. Syst. Biol. 2003, 52, 696-704. [CrossRef] [PubMed]

63. Darriba, D.; Taboada, G.L.; Doallo, R.; Posada, D. jModelTest 2: More models, new heuristics and parallel computing. Nat. Methods 2012, 9, 772. [CrossRef]

64. Guindon, S.; Dufayard, J.F.; Lefort, V.; Anisimova, M.; Hordijk, W.; Gascuel, O. New algorithms and methods to estimate maximum-likelihood phylogenies: Assessing the performance of PhyML 3.0. Syst. Biol. 2010, 59, 307-321. [CrossRef] [PubMed]

65. Swofford, D.L. PAUP* 4.0: Phylogenetic Analysis Using Parsimony ( ${ }^{*}$ And Other Methods); Sinauer Associates: Sunderland, MA, USA, 2003.

66. Ronquist, F.; Huelsenbeck, J.P. MrBayes 3: Bayesian phylogenetic inference under mixed models. Bioinformatics 2003, 19, 1572-1574. [CrossRef] [PubMed]

67. Rambaut, A.; Drummond, A.J. Tracer v1.4. 2007. Available online: http:/ / beast.bio.ed.ac.uk/Tracer (accessed on 20 June 2020).

68. Lombard, L.; Merwe, N.V.; Groenewald, J.; Crous, P. Generic concepts in Nectriaceae. Stud. Mycol. 2015, 80, 189-245. [CrossRef] [PubMed]

69. Mańka, M.; Łakomy, P.; Cieślak, R.; Szynkiewicz, A. Fungi inhabiting Fagus sylvatica seeds after harvest and after drying. Phytopathologia 2012, 65, 39-43.

70. Salerno, M.I.; Lori, G.A. Association of seed-borne Fusarium species on Pinus ponderosa with germination and seedling viability in Argentina. For. Pathol. 2007, 37, 263-271. [CrossRef]

71. Booth, C. The Genus Fusarium; Commonwealth Mycological Institute: Kew, Surrey, UK; The Eastern Press Limited London and Reading: London, UK, 1971; pp. 1-237.

72. Summerell, B.A.; Leslie, J.F.; Liew, E.C.Y.; Laurence, M.H.; Bullock, S.; Petrovic, T.; Bentley, A.R.; Howard, C.G.; Peterson, S.A.; Walsh, J.L.; et al. Fusarium species associated with plants in Australia. Fungal Divers. 2011, 46, 1-27. [CrossRef]

73. Szynkiewicz, A.; Kwaśna, H. The effects of fungi from acorns with symptoms of black rot and necrotic twigs of oak on Quercus seedlings. Phytopathol. Pol. 2004, 32, 49-59.

74. Wit, M.; Sierota, Z.; Oszako, T.; Mirzwa-Mróz, E.; Wakuliński, W. Fusarium spp. na nadziemnych organach zamierających dębów-nowe zagrożenie? Sylwan 2015, 159, 403-410. [CrossRef]

75. Domsch, K.H.; Gams, W.; Anderson, T.-H. Compendium of Soil Fungi; IHW-Verlag Press: Eching, Germany, 1993.

76. Ivanová, H.; Hrehová, L'.; Pristaš, P. First confirmed report on Fusarium sporotrichioides on Pinus ponderosa var. jeffreyi in Slovakia. Plant Protect. Sci. 2016, 52, 250-253. [CrossRef]

77. Anderson, R.L. New method for assessing contamination of slash and loblolly pine seeds by Fusarium moniliforme var. subglutinans. Plant Dis. 1986, 70, 452-453. [CrossRef]

78. Jankowiak, R. Fungi occurring in acorn of Quercus robur L. infested by insects. Acta Sci. Pol. Silv. Colendar. Rat. Ind. Lignar. 2008, 7, 19-29. Available online: http://www.forestry.actapol.net/issue1/volume/2_1_2008.pdf (accessed on 20 February 2021).

79. Jankowiak, R.; Stępniewska, H.; Bilański, P.; Taerum, S.J. Fungi as potential factor limiting natural regeneration of pedunculate oak (Quercus robur L.) in mixed-species forest stands in Poland. (unpublished; manuscript in preparation).

80. Zakaria, L.; Foong, M.K.; Hsuan, H.M.; Zakaria, M.; Salleh, B. Fusarium species isolated from Mangrove soil in Kampung Pantai Acheh, Balik Pulau, Pulau Pinang, Malaysia. Trop. Life Sci. Res. 2010, 21, 21-29.

81. Zakaria, L.; Azaman, R.S. Fusarium species isolated from forest soil samples. Mal. J. Microbiol. 2011, 7, $171-174$.

82. Akare, S.M.; Tagade, W.Y.; Warghat, A.R.; Nargal, A.; Bhardwaj, A. Culturable fungal diversity associated with forest leaf litter from Bhandara District of Maharashtra, India. Biodiversitas 2016, 17, 349-358.

83. Urbanová, M.; Šnajdr, J.; Baldrian, P. Composition of fungal and bacterial communities in forest litter and soil is largely determined by dominant trees. Soil Biol. Biochem. 2015, 84, 53-64. [CrossRef]

84. Dastogeer, K.M.G.; Tumpa, F.H.; Sultana, A.; Akter, M.A.; Chakraborty, A. Plant microbiome-an account of the factors that shape community composition and diversity. Curr. Plant Biol. 2020, 23, 100161. [CrossRef] 